\title{
Can mineral supplementation modify the characteristics of young buffalo ejaculate?
}

\section{Pode a suplementação mineral influenciar as características do ejaculado de touros búfalos jovens?}

\author{
Rinaldo Batista Viana ${ }^{1 *}$; Bruno Moura Monteiro ${ }^{2}$; Elyzabeth da Cruz Cardoso ${ }^{3}$; \\ José Dantas Ribeiro Filho4; Rodrigo dos Santos Albuquerque ${ }^{5}$; Paulo Marcelo \\ Albuquerque de Melo ${ }^{6}$; Pietro Sampaio Baruselli ${ }^{7}$
}

\begin{abstract}
This study aimed to determine the influence of mineral supplementation on the concentration of macroelements and microelements in the seminal plasma and the semen characteristics of young buffaloes. To this end, 60 animals were kept under rotational grazing and were randomly divided into two groups: G-Bov (conventional mineral supplement recommended for bovine cattle; $n=30$ ) and G-Buf (mineral supplement recommended for buffaloes; $\mathrm{n}=30$ ). Mineral supplement consumption was calculated from the difference between the amount of supplement offered and the leftover bunk, calculated every 28 days. Eight ejaculates from each animal were collected. The means of the response variables were analyzed using the Kruskal-Wallis test, with a significance level of 5\%, and Pearson's correlation was analyzed between the concentration of minerals in seminal plasma and fresh semen characteristics. Animals in the G-Buf group had lower mineral supplement consumption (G-Bov $=83.18$ vs. G-Buf $=77.14 \mathrm{~g} \mathrm{AU}^{-1}$ day $^{-1}, \mathrm{P}<0.05$ ) and had higher ejaculate volume, sperm motility, sperm vigor, and sperm mass motility than did the animals in the G-Bov group. This research presented the concentration of macroelements and microelements in the seminal plasma of buffaloes receiving different mineral supplements. In addition, the study concluded that the physical and morphological characteristics of the semen of young buffaloes are influenced by the formulation of the mineral supplement, which resulted in better sperm quality in the animals receiving a species-specific supplement. Among the minerals present in buffalo seminal plasma, phosphorus is the element that shows the highest positive correlation with semen characteristics.
\end{abstract}

Key words: Bubalus bubalis. Mineral mixture. Reproduction. Semen.

${ }^{1}$ Prof., Programa de Pós-Graduação em Reprodução Animal na Amazônia, ReproAmazon, Instituto da Saúde e Produção Animal, Universidade Federal Rural da Amazônia, UFRA, Belém, PA, Brasil. E-mail: rinaldovianna@hotmail.com

2 Prof., Programa de Pós-graduação em Reprodução Animal na Amazônia, ReproAmazon, Universidade Federal Rural da Amazônia - Campus de Paragominas, UFRA, Paragominas, PA, Brasil. E-mail: brunomouramonteiro@hotmail.com

${ }^{3}$ Prof ${ }^{\text {a }}$, Universidade Federal Fluminense, UFF, Nova Friburgo, RJ, Brasil. E-mail: elyzabethcardoso@hotmail.com

${ }^{4}$ Prof., Programa de Pós-graduação em Medicina Veterinária, Departamento de Medicina Veterinária, Universidade Federal de Viçosa, UFV, Viçosa, MG, Brasil. E-mail: dantas@ufv.br

${ }^{5}$ Prof., Universidade da Amazônia, UNAMA, Belém, PA, Brasil. E-mail: rdsa20@gmail.com

6 Médico Veterinário Autônomo, Capitão Poço, PA, Brasil. E-mail: marcelo_vet2007@yahoo.com.br

7 Prof., Programa de Pós-Graduação em Reprodução Animal, Departamento de Reprodução Animal, Faculdade de Medicina Veterinária e Zootecnia, Universidade de São Paulo, USP, São Paulo, SP, Brasil. E-mail: barusell@usp.br

* Author for correspondence 


\section{Resumo}

Com o objetivo de verificar a influência do suplemento mineral consumido na concentração dos macro e microelementos no plasma seminal e nas características do sêmen de búfalos, 60 bezerros de 10 meses de idade foram mantidos sob lotação intermitente por 14 meses, consumindo, ad libitum, dois suplementos minerais distintos e divididos aleatoriamente em dois grupos: G-Bov (suplemento mineral convencional recomendado para bovinos; $\mathrm{n}=30$ ) e G-Buf (suplemento mineral específico para búfalos; $\mathrm{n}=30$ ). O consumo do suplemento mineral foi calculado a partir da diferença entre a quantidade de suplemento oferecido e a sobra mensal do cocho. Dos búfalos a partir dos 22 meses de idade foram realizadas oito colheitas de sêmen de cada animal. As médias das variáveis foram analisadas por meio do teste de Kruskal-Wallis, com nível de significância de 5\%, também foi analisada a correlação de Pearson entre a concentração de minerais no plasma seminal e as características do ejaculado. Observou-se que os animais do G-Buf mesmo consumindo menos suplemento mineral (G-Bov $=83,18$ vs. G-Buf $=77,14 \mathrm{~g} \mathrm{UA}^{-1}$ dia $\left.^{-1} ; \mathrm{P}<0,05\right)$ obtiveram maior volume do ejaculado e melhores motilidade, vigor e turbilhonamento. Esta pesquisa apresenta as concentrações de macro e microelementos no plasma seminal de búfalos suplementados com diferentes formulações minerais. Além disso, concluiuse que as características físicas e morfológicas do sêmen de búfalos jovens são influenciadas pelo tipo de suplementação mineral, apresentando sêmen de melhor qualidade em búfalos suplementados com suplementos específicos para a espécie. Dos minerais presentes no plasma seminal de búfalos, o fósforo é o elemento que mostra maior correlação positiva com as características seminais no ejaculado.

Palavras-chave: Bubalus bubalis. Mistura mineral. Reprodução. Sêmen.

\section{Introduction}

Semen presents a variable constitution between different species and even between individuals of the same species (ANDRABI, 2009). Changes in the management of bulls in the form of modifications in diet and nutrition can also influence semen production and quality in the buffalo. Seminal plasma is known to have a stimulatory effect on sperm motility owing to the presence of several specific substances; however, information on these substances, particularly the macroelements and microelements in the seminal plasma of buffaloes, is scarce and studies do not address all the elements (EGHBALI et al., 2010a).

Microelements are essential for metabolic, enzymatic, and cellular reactions, and play roles in somereproductive functions such as spermatogenesis and sperm maturation (AHMAD et al., 2010). The ionic composition of seminal plasma varies among different species, and calcium (Ca), magnesium $(\mathrm{Mg})$, and zinc $(\mathrm{Zn})$ are some of the main ions present in seminal plasma (TVRDÁ et al., 2013). Although a positive correlation exists between testicular measurements and the morphofunctional characteristics of semen (LUZ et al., 2013), and between sperm evaluation and the concentration of some minerals in the semen (EGHBALI et al., 2010b), no study in the literature has investigated the influence of mineral nutrition on the quality and mineral constitution of the ejaculate.

Knowledge about semen constitution is relevant not only for understanding the reproductive physiology of male animals, but also for semen processing, aiming at the adoption of biotechniques applied to reproduction (SÁ FILHO et al., 2011) such as artificial insemination, which is an essential biotechnology for the extensive use of the genetic material of breeding animals (BARUSELLI et al., 2012).

Therefore, the aims of this study were to determine the macroelement and microelement concentrations in the seminal plasma of buffaloes, to verify the influence of mineral supplement consumption on the concentration of these elements in seminal plasma and on the physical and morphological characteristics of semen, as well 
as to correlate the concentration of the minerals in seminal plasma with the physical and morphological semen characteristics.

\section{Materials and Methods}

This experiment used 60 buffaloes raised in a property located in Ipixuna do Pará (2057'56.65 “S; 48000'03.70”O), PA, Brazil. The animals were kept on pastures of Urochloa (Syn. Brachiaria) brizantha cv. Marandu, under intermittent or rotational stocking, and randomly divided into two groups: G-Bov (30 buffaloes that consumed, ad libitum, a recommended mineral supplement for cattle) and G-Buf (30 buffaloes that consumed, ad libitum, a mineral supplement recommended for buffaloes in the stages of creates, recreates, and fattening).

After weaning, at 8 months of age, the animals had 2 months of adaptation to the management system adopted before the experiment was initiated. During 14 months under the same experimental conditions, the animals of both groups were kept in two separate pastures, each measuring 18 ha in area. The pastures were subdivided into 12 paddocks of 1.5 ha each. Every 3 days, the animals were rotated between the paddocks, with each group rotated in its respective pasture. Every 28 days, the groups of animals were alternated between the two pastures, to offer the same qualitative-quantitative availability of forage, both in the dry and rainy seasons.
Every 56 days, the qualitative-quantitative availability of forage in each of the pastures used in the experiment was determined. Three forage samples were collected from each pasture by using a wooden square measuring $0.50 \mathrm{~m}^{2}$ in area. The squares were cast randomly and manually, and the grass inside the square was collected by cutting at a height of approximately $10 \mathrm{~cm}$ above the ground. The harvested forage was packed in individual bags and weighed immediately to calculate the availability of green matter. The samples from each paddock were then homogenized, and a single combined sample was taken and sent to the laboratory for chemical analyses and dry matter availability calculations per hectare.

The nutritional composition analysis of the forage followed the techniques described by Silva (1998), and the mineral analysis of the forage followed the description of Milles et al. (2001). The readings were performed using flame atomic absorption spectrophotometry and colorimetry.

The calculation of the monthly amount of mineral supplement offered (Table 1) was based on an initial daily intake estimated at $120 \mathrm{~g} \mathrm{AU}^{-1}$. The mineral supplement consumed was offered in bunks, with top and lateral coverage, measuring about $4 \mathrm{~m}$ in length. The monthly intake of the mineral supplement was calculated from the difference between the amount of supplement offered and the leftover bunk, calculated every 28 days. 
Table 1. Levels of guarantee of the mineral elements used in the experimental groups.

\begin{tabular}{lcc}
\hline \multirow{2}{*}{ Element } & \multicolumn{2}{c}{ Guarantee levels $^{1}$} \\
\cline { 2 - 3 } & G-Bov* & G-Buf** \\
\hline Calcium & $197.5 \mathrm{~g}$ & $190.0 \mathrm{~g}$ \\
Phosphorus & $110.0 \mathrm{~g}$ & $82.00 \mathrm{~g}$ \\
Sulfur & $28.00 \mathrm{~g}$ & $12.00 \mathrm{~g}$ \\
Magnesium & $19.00 \mathrm{~g}$ & $10.00 \mathrm{~g}$ \\
Sodium & $50.00 \mathrm{~g}$ & $70.00 \mathrm{~g}$ \\
Fluorine (Maximum) & $1,100.0 \mathrm{mg}$ & $820.0 \mathrm{mg}$ \\
Cobalt & $200.0 \mathrm{mg}$ & $175.0 \mathrm{mg}$ \\
Copper & $1,150.0 \mathrm{mg}$ & $1,600.0 \mathrm{mg}$ \\
Iron & $1,000.0 \mathrm{mg}$ & $1.000 .0 \mathrm{mg}$ \\
Iodine & $170.0 \mathrm{mg}$ & $180.0 \mathrm{mg}$ \\
Manganese & $1,625.0 \mathrm{mg}$ & $1,400.0 \mathrm{mg}$ \\
Nickel & - & $20.00 \mathrm{mg}$ \\
Selenium & $30.50 \mathrm{mg}$ & $27.00 \mathrm{mg}$ \\
Zinc & $4,500.0 \mathrm{mg}$ & $4,500.0 \mathrm{mg}$ \\
\hline
\end{tabular}

${ }^{1}$ Product security levels for each 1,000 g of mineral mixture; *Indicated for creates, recreates, and fattening of dairy and beef cattle (calcium carbonate, dicalcium phosphate, ventilated sulfur, magnesium oxide, sodium chloride, cobalt sulfate, copper sulfate, iron sulfate, potassium iodate, manganese sulfate, sodium selenite, and zinc oxide); **Indicated for supplementation of creates, recreates, and fattening of buffaloes, reared on pasture (calcium carbonate, dicalcium phosphate, ventilated sulfur, magnesium oxide, sodium chloride, cobalt sulfate, copper sulfate, iron sulfate, calcium iodate, manganese sulfate, nickel sulfate, sodium selenite, zinc sulfate, and dry sugar cane yeast).

The animals were also weighed every 28 days during the 14 months of the experiment. Weight gain was calculated within a 28-day interval on the basis of the differences between the initial and final weights of the animals fasted for $12 \mathrm{~h}$. The average daily weight gain was estimated using the following formula: $\mathrm{DWG}=[(\mathrm{Wm}-\mathrm{Wb}) / 28]$, where: $\mathrm{DWG}=$ daily weight gain $\left(\mathrm{g} \mathrm{day}^{-1}\right) ; \mathrm{Wb}=$ mean weight at the beginning of each 28-day interval; $\mathrm{Wm}=$ mean weight after each 28-day interval; and $\mathrm{n}=1,2$, 3.....12.

From 10 to 24 months of age, measurements of the right and left testicles were performed every 56 days. These measurements included the height, width, and depth, as well as scrotal circumference (SC). The length or height of the testicles was measured using a pachymeter, and the head and tail of the epididymis were excluded in the dorsalventral direction. The width was measured using a pachymeter, with the measurement taken in the median region of each testicle, in the lateral-medial direction. The depth was also measured using a pachymeter, with the measurement taken in the median region of each testicle, in the craniocaudal direction. The SC was measured in centimeters (cm) by using an appropriate metallic tape measure, which was shaped like a loop and was placed at the point equivalent to the largest diameter, including both the gonads and scrotal skin, according to the recommendations by Vale (1994b).

From 22 months of age (8 months of age at weaning, 2 months of adaptation, and 12 months of the prepubertal period), semen samples were collected weekly from all animals by using an electro-ejaculator. During the experiment, eight semen samples were collected from each animal; however, only the buffaloes with $100 \%$ successful harvests were retained in the experiment, thus accounting to a total of 432 semen samples of 54 buffaloes (27 animals in the G-Bov group $=216$ samples; 27 animals in the G-Buf group $=216$ samples). 
Immediately after each semen collection, macroscopic and microscopic evaluations were performed through ejaculate analysis, which was initiated by visual measurement of the volume $(\mathrm{mL})$ directly in the graduated collection tube. To obtain the sperm concentration (spermatozoa $\times 10^{6} \mathrm{~mL}^{-1}$ ), a $5-\mu \mathrm{L}$ sample of semen was diluted in $1 \mathrm{~mL}$ of buffered formalin solution (dilution 1: 200), and a small aliquot of this mixture $(10 \mu \mathrm{L})$ was placed in the Neubauer cell counting chamber until it was completely filled (VALE, 1994a; PEIXOTO et al., 2012). The motility, vigor, and mass motility of the spermatozoa were evaluated using light microscopy. Mass motility was evaluated by placing a drop of fresh semen on a slide $(10 \times$ magnification $)$. Using another drop of semen placed between a slide and a cover slip, motility and vigor were quantified $(100 \times$ magnification). Motility was expressed as a percentage of motile spermatozoa, while vigor (1 to 5 scale) and mass motility ( 0 to 5 scale) were expressed as scores; in addition, seminal $\mathrm{pH}$ was determined using strips of MERCK $^{\circledR}$ reagents ( ${ }^{\circ} 2019$ Merck KGaA, Darmstadt, Germany) (VALE, 1994a).

The Congo red staining technique using the Cerovsky method (CEROVSKY, 1976) was performed to evaluate the plasma membrane integrity of fresh semen, where 200 cells were analyzed per sample, and the results were presented as the percentage of cells with intact plasma membranes. Sperm morphological analysis was performed using buffered formalin solution; 200 spermatozoa per sample were counted and classified into those with major and minor defects, and these were taken together to obtain the total defects. These evaluations were always performed by the same operator using simple microscopy with phase contrast, following the recommendations by Vale et al. (1991).

After all the physical and morphological analyses, the semen was centrifuged at $3000 \mathrm{~g}$ for 20 min. The supernatant was removed, aliquoted into microtubes, and frozen at $-20^{\circ} \mathrm{C}$ for further analysis of mineral concentrations. The analysis of minerals in seminal plasma followed the technique described by Milles et al. (2001) and validated by Viana et al. (2011), which is recommended for the analysis of minerals in blood plasma. The analysis of minerals was performed using a solution containing $1 \mathrm{~mL}$ of seminal plasma in $9 \mathrm{~mL}$ of $10 \%$ trichloroacetic acid solution for protein precipitation. In the supernatant, after the respective dilutions, the concentrations of copper $(\mathrm{Cu})$, cobalt $(\mathrm{Co})$, Zinc $(\mathrm{Zn})$, iron $(\mathrm{Fe})$, and manganese $(\mathrm{Mn})$ were determined. For $\mathrm{Ca}$, $\mathrm{Mg}$, and phosphorus (P), $9 \mathrm{~mL}$ of a $1 \%$ lanthanum chloride solution was added to $1 \mathrm{~mL}$ of this supernatant. The concentration of $\mathrm{P}$ was measured using colorimetry, and those of $\mathrm{Ca}, \mathrm{Mg}, \mathrm{Cu}, \mathrm{Co}$, $\mathrm{Fe}, \mathrm{Zn}$, and $\mathrm{Mn}$ were measured using flame atomic absorption spectrophotometry (Varian SpectrAA 55B, Melbourne, Australia). The analyses were carried out at the Laboratory of Mineral Analysis of the Institute of Animal Health and Production, Amazon Federal Rural University.

The experimental design was entirely randomized. The means of quantitative forage availability, mineral supplement consumption, animal weight, physical-morphological characteristics of semen, and concentration of minerals in seminal plasma were compared between the treatments by using the Kruskal-Wallis test, adopting a significance level of 5\%. Pearson's correlation between the concentration of minerals in seminal plasma and the variables related to the physical-morphological characteristics of the ejaculate was also analyzed. All analyses were performed using the SAS program version 9.0 (SAS/STAT, SAS Institute Inc., Cary, NC).

\section{Results and Discussion}

No difference was observed between the qualitative-quantitative availability of forage for the animals in the different treatment groups $(P>0.05)$, both in the rainy and dry seasons (Table 2). The mean mineral supplement intake was $80.16 \mathrm{~g} \mathrm{UA}^{-1}$ day $^{-1}$, where G-Bov supplementation was higher than G-Buf supplementation (Figure 1). 
Table 2. Means and standard deviations obtained for the availability and nutritional values of Urochloa (Syn. Brachiaria) brizantha $\mathrm{cv}$. Marandu, in relation to the group and time of year.

\begin{tabular}{|c|c|c|c|c|c|c|}
\hline \multirow{2}{*}{ Variable } & \multicolumn{3}{|c|}{ Rainy season } & \multicolumn{3}{|c|}{ Dry season } \\
\hline & G-Bov & G-Buf & $\mathbf{P}$ & G-Bov & G-Buf & $\mathbf{P}$ \\
\hline Green matter ha' ${ }^{-1}$ (tonne) & $7.02 \pm 0.24$ & $5.75 \pm 2.95$ & 0.4647 & $6.16 \pm 1.14$ & $6.01 \pm 1.51$ & 0.8273 \\
\hline Dry matter ha-1 (tonne) & $2.03 \pm 9.74$ & $1.86 \pm 1.09$ & 1.0000 & $2.55 \pm 1.52$ & $3.00 \pm 2.44$ & 0.8273 \\
\hline Dry matter (\%) & $30.69 \pm 1.73$ & $29.24 \pm 11.33$ & 0.9168 & $40.98 \pm 21.19$ & $45.79 \pm 25.34$ & 0.8273 \\
\hline Humidity (\%) & $69.31 \pm 9.94$ & $70.76 \pm 11.33$ & 0.9168 & $59.02 \pm 21.19$ & $54.21 \pm 25.54$ & 0.8273 \\
\hline Crude protein (\%) & $6.15 \pm 2.08$ & $5.53 \pm 1.21$ & 0.6015 & $4.73 \pm 1.25$ & $5.17 \pm 1.41$ & 0.2752 \\
\hline Ethereal extract (\%) & $1.99 \pm 0.48$ & $2.28 \pm 1.19$ & 0.9168 & $1.18 \pm 0.30$ & $1.76 \pm 0.59$ & 0.2752 \\
\hline Neutral detergent fiber (\%) & $60.54 \pm 2.44$ & $60.39 \pm 3.73$ & 0.7540 & $65.13 \pm 6.06$ & $65.65 \pm 2.75$ & 1.0000 \\
\hline Gross energy (cal kg-1) & $4.61 \pm 0.15$ & $4.66 \pm 4.66$ & 0.6004 & $4.15 \pm 0.48$ & $4.44 \pm 0.15$ & 0.2752 \\
\hline Phosphorus (\%) & $0.07 \pm 0.02$ & $0.05 \pm 0.04$ & 0.6704 & $0.03 \pm 0.02$ & $0.02 \pm 0.02$ & 1.0000 \\
\hline Calcium (\%) & $1.70 \pm 0.15$ & $1.72 \pm 0.18$ & 1.0000 & $1.77 \pm 0.23$ & $1.86 \pm 0.18$ & 0.8273 \\
\hline Magnesium (\%) & $0.64 \pm 0.10$ & $0.69 \pm 0.07$ & 0.2933 & $0.46 \pm 0.13$ & $0.43 \pm 0.06$ & 1.0000 \\
\hline Sodium (\%) & $0.41 \pm 0.00$ & $0.42 \pm \pm 0.42$ & 0.4795 & $0.48 \pm \pm 0.29$ & $0.52 \pm \pm 0.54$ & 1.0000 \\
\hline Potassium (\%) & $8.73 \pm \pm 3.32$ & $6.13 \pm 6.13$ & 0.4386 & $3.71 \pm 3.53$ & $4.69 \pm 5.61$ & 1.0000 \\
\hline Copper $\left(\mathrm{mg} \mathrm{kg}^{-1}\right)$ & $1.83 \pm 0.90$ & $1.36 \pm 0.79$ & 0.2506 & $2.09 \pm 0.69$ & $2.73 \pm 1.43$ & 0.8273 \\
\hline Zinc $\left(\mathrm{mg} \mathrm{kg}^{-1}\right)$ & $34.53 \pm 7.13$ & $41.15 \pm 8.67$ & 0.2506 & $57.31 \pm 9.07$ & $51.86 \pm 3.47$ & 0.5127 \\
\hline Iron $\left(\mathrm{mg} \mathrm{kg}^{-1}\right)$ & $159.2 \pm 191.55$ & $149.2 \pm 148.98$ & 0.7540 & $67.86 \pm 4.76$ & $76.27 \pm 27.12$ & 0.5127 \\
\hline Manganese $\left(\mathrm{mg} \mathrm{kg}^{-1}\right)$ & $157.6 \pm 41.88$ & $172.4 \pm 50.50$ & 0.4647 & $223.3 \pm 51.21$ & $181.6 \pm 63.84$ & 0.2752 \\
\hline Cobalt $\left(\mathrm{mg} \mathrm{kg}^{-1}\right)$ & $0.41 \pm 0.51$ & $0.51 \pm 0.32$ & 0.4633 & $0.36 \pm 0.62$ & $0.08 \pm 0.08$ & 1.0000 \\
\hline
\end{tabular}

G-Bov = conventional mineral supplement recommended for bovine cattle; G-Buf = mineral supplement recommended for buffaloes.

Figure 1. Average intake of mineral supplements $\left(\mathrm{g} \mathrm{AU}^{-1} \mathrm{day}^{-1}\right)$ by young buffaloes reared in intermittent stocking and submitted to different mineral nutritional managements. G-Bov (conventional mineral supplement recommended for bovine cattle) and G-Buf (mineral supplement recommended for buffaloes).

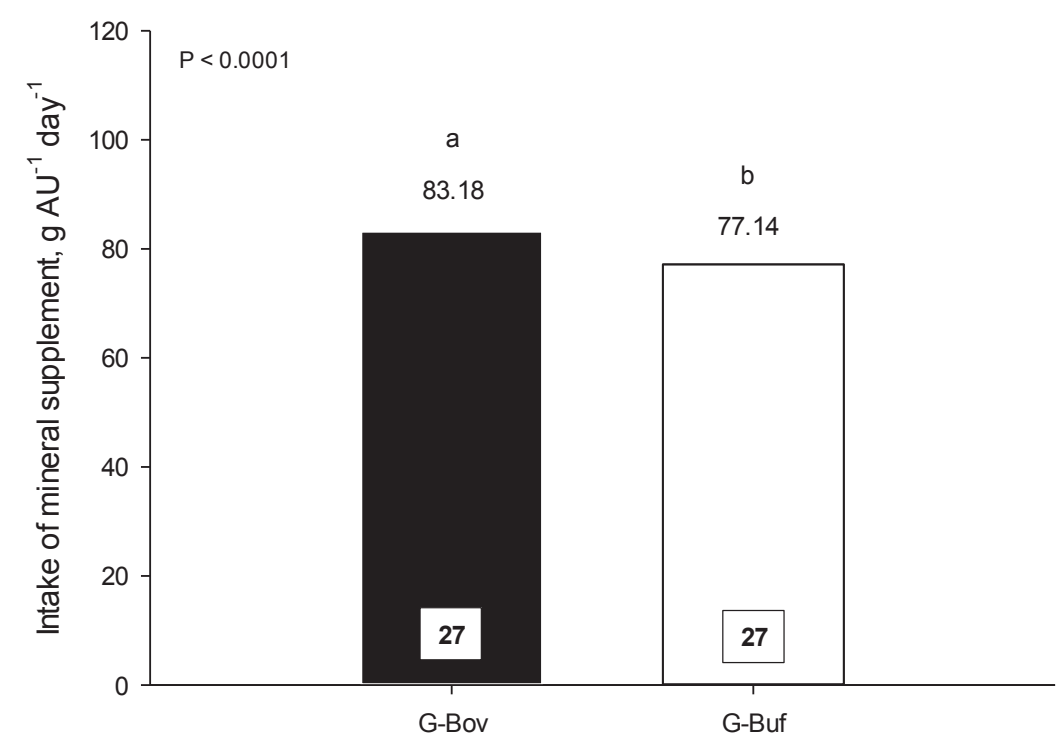


At the beginning of the experiment, no significant difference was observed in the mean weight of the animals in the G-Bov and G-Buf groups. However, at the end of the 14-month experiment, the animals in the G-Buf group had a higher mean weight (Table 3). This increase of $60.06 \mathrm{~kg}$ in the mean weight of the G-Buf group was probably caused by a significant daily weight gain of approximately about $143.93 \mathrm{~g} \mathrm{day}^{-1}$ achieved by the animals in this group. Therefore, a significant increase in the development of the animals in the G-Buf group occurred, possibly because of the use of the mineral supplement most appropriate to the species. In addition to this higher average weight gain at the end of the experiment and the better average daily weight gain of the animals in the G-Buf group, the possibility of lower consumption of mineral supplement could have occurred, which could consequently represent a profitability for the breeders.

Animals in the G-Buf group yielded greater ejaculate volume, besides showing better sperm motility, sperm vigor, and sperm mass motility (Table 4). However, no difference was observed in sperm concentration between the two groups. Animals in the G-Bov group presented higher values for spermatic thin-head defects, total sperm defects, and total number of abnormal spermatozoa $(\mathrm{P}<0.05)$.

These values for the physical characteristics (motility, vigor, and concentration) of the buffalo's ejaculate in both the groups were lower than those described by Eghbali et al. (2010a), while the ejaculate volume was similar. This was probably due to the different methods of semen collection used, since in the present study, electro-ejaculation was opted for because the animals were young. Moreover, significant amounts of seminal plasma were required for determining the macroelement and microelement concentrations, which was the main objective of this research.

Table 3. Means and standard deviations, as well as minimum and maximum values, of the initial and final mean weights $(\mathrm{kg})$ and the average daily weight gain $\left(\mathrm{g}_{\text {day }}{ }^{-1}\right)$ of buffaloes reared in intermittent stocking and consuming different mineral supplements.

\begin{tabular}{|c|c|c|c|}
\hline \multirow[t]{2}{*}{ Group } & \multicolumn{2}{|c|}{$\begin{array}{c}\text { Weight (kg) } \\
\text { Mean } \pm \text { standard deviations } \\
\text { (minimum-maximum values) }\end{array}$} & \multirow[t]{2}{*}{$\begin{array}{l}\text { Daily weight } \\
\text { gain }\left(\mathrm{g} \mathrm{day}^{-1}\right)\end{array}$} \\
\hline & Initial & Final & \\
\hline $\begin{array}{c}\text { G-Bov } \\
\text { Mineral supplement for cattle } \\
(\mathrm{n}=27)\end{array}$ & $\begin{array}{c}220.5 \pm 26.6 \\
(185.0-285.0)\end{array}$ & $\begin{array}{l}395.2 \pm 69.6^{b} \\
(220.0-530.0)\end{array}$ & $445.6 \pm 138.1^{b}$ \\
\hline $\begin{array}{c}\text { G-Buf } \\
\text { Mineral supplement for buffaloes } \\
(\mathrm{n}=27)\end{array}$ & $\begin{array}{c}224.2 \pm 30.4 \\
(172.0-305.0)\end{array}$ & $\begin{array}{l}455.3 \pm 43.8^{\mathrm{a}} \\
(369.0-550.0)\end{array}$ & $589.6 \pm 89.8^{a}$ \\
\hline
\end{tabular}

Different superscript letters on the same column indicate significant differences $(\mathrm{P}<0.0001)$. 
Table 4. Means and standard deviations for the physical and morphological analyses of the semen of young buffaloes reared in rotational stocking and submitted to different mineral nutritional managements.

\begin{tabular}{lccc}
\hline Characteristic & G-Bov $(\mathrm{n}=216)$ & G-Buf $(\mathrm{n}=216)$ & \multirow{2}{*}{ P value } \\
\cline { 1 - 2 } Physical characteristics of the ejaculate & & & 0.0001 \\
\hline Volume (mL) & $3.46 \pm 1.82^{\mathrm{b}}$ & $4.30 \pm 1.93^{\mathrm{a}}$ & 0.0001 \\
Motility (\%) & $51.91 \pm 60.72^{\mathrm{b}}$ & $58.67 \pm 21.70^{\mathrm{a}}$ & 0.0009 \\
Vigor (1-5) & $1.90 \pm 1.34^{\mathrm{b}}$ & $2.17 \pm 0.93^{\mathrm{a}}$ & 0.0021 \\
Mass motility (0-5) & $0.57 \pm 0.83^{\mathrm{b}}$ & $0.98 \pm 1.16^{\mathrm{a}}$ & 0.7000 \\
Sperm concentration $\left(\times 10^{6} \mathrm{~mL}^{-1}\right)$ & $206 \times 10^{6} \pm 420 \times 10^{6}$ & $255 \times 10^{6} \pm 532 \times 10^{6}$ & 0.0162 \\
pH & $8.4 \pm 0.25^{\mathrm{b}}$ & $8.32 \pm 0.36^{\mathrm{a}}$ & \\
Morphological characteristics of ejaculate & & & \\
Head defects & $10.30 \pm 9.35(5.15 \%)$ & $8.90 \pm 9.25(4.45 \%)$ & 0.0713 \\
Midpiece defects (a) & $0.99 \pm 2.28(0.50 \%)$ & $0.85 \pm 4.78(0.43 \%)$ & 0.8434 \\
Defect of the main piece (b) & $31.60 \pm 20.65(15.80 \%)^{\mathrm{a}}$ & $24.83 \pm 17.65(12.42 \%)^{\mathrm{b}}$ & 0.0017 \\
Tail defects (c) & $4.21 \pm 5.63(2.11 \%)$ & $4.11 \pm 7.94(2.05 \%)$ & 0.7894 \\
Tail defects total (a+b+c) & $36.80 \pm 21.57(18.40 \%)^{\mathrm{a}}$ & $29.79 \pm 20.32(14.90 \%)^{\mathrm{b}}$ & 0.0054 \\
Normal sperm & $152.9 \pm 22.46(76.45 \%)^{\mathrm{a}}$ & $160.9 \pm 22.13(80.46 \%)^{\mathrm{b}}$ & 0.0021 \\
Abnormal sperm & $47.10 \pm 22.46(23.55 \%)^{\mathrm{a}}$ & $38.69 \pm 21.07(19.54 \%)^{\mathrm{b}}$ & 0.0010 \\
\hline
\end{tabular}

G-Bov = conventional mineral supplement recommended for bovine cattle; G-Buf = mineral supplement recommended for buffaloes. Different superscript letters on the same line indicate differences for each group in each experiment.

As there was no change in the qualitative and quantitative availability of forage $(\mathrm{P}>0.05)$, since the animals were contemporaneous and of the same genetic grouping, and since they were reared under the same edaphoclimatic conditions and similar management, the better semen quality of the buffaloes in the G-Buf group could probably be attributed to the mineral nutritional management offered to the animals in this group. This better semen quality is possibly associated with the better testicular development of buffaloes in the G-Buf group, since these animals achieved a constant and progressive testicular growth (Figure 2), unlike those in the G-Bov group. At the beginning of the study, the mean testicular biometric measurements for the G-Buf and G-Bov groups were similar; however, at the end of the experiment, all the mean measurements were higher in the G-Buf group than in the G-Bov group (Table 5). 
Figure 2. Scrotal circumference $(\mathrm{cm})$ of young buffaloes reared in intermittent stocking and submitted to different mineral nutritional managements. G-Bov (conventional mineral supplement recommended for bovine cattle) and G-Buf (mineral supplement recommended for buffaloes).

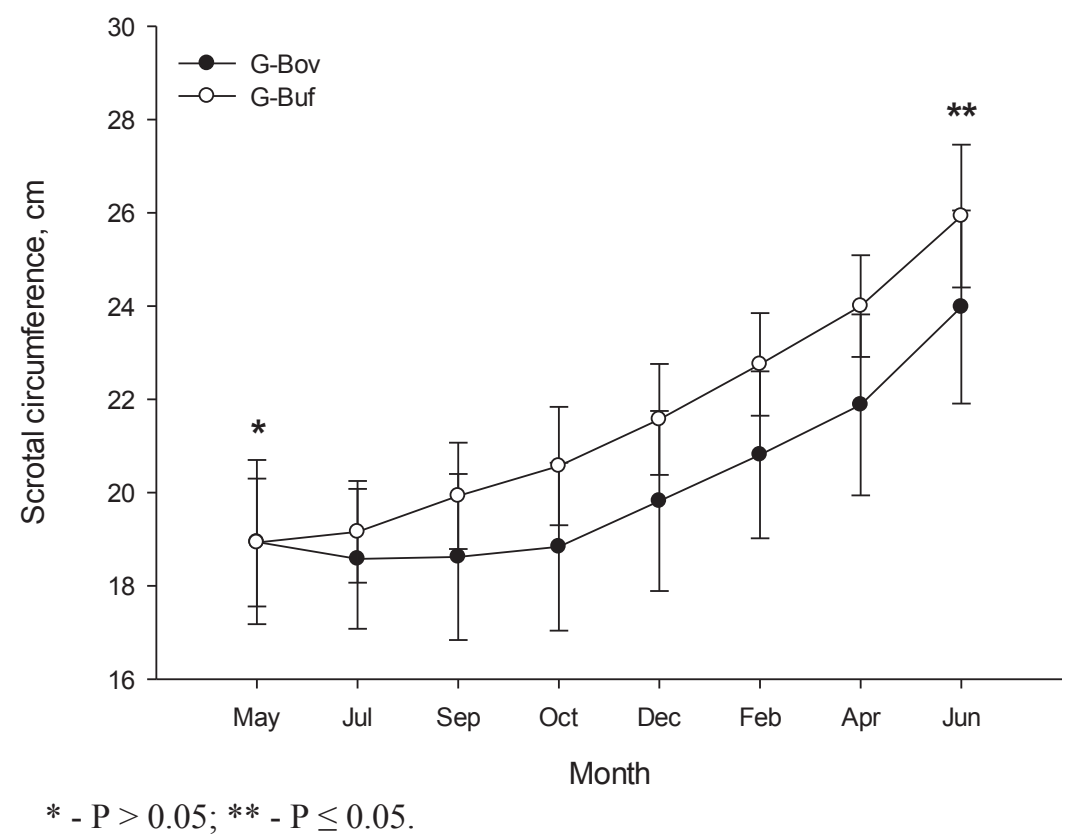

Table 5. Means and standard deviations, as well as minimum and maximum testicular biometric values of young buffaloes created in rotational grazing and submitted to different nutritional mineral managements at the beginning (10 months old) and end of the experiment (24 months old).

\begin{tabular}{|c|c|c|c|c|c|c|}
\hline \multirow{3}{*}{ Variable } & \multicolumn{3}{|c|}{$\begin{array}{c}\text { Beginning of the experiment } \\
(10 \text { months old })\end{array}$} & \multicolumn{3}{|c|}{$\begin{array}{l}\text { End of experiment } \\
\text { ( } 24 \text { months old })\end{array}$} \\
\hline & $\begin{array}{l}\text { Group G-Bov } \\
\text { Mineral mix of the } \\
\text { farm }\end{array}$ & $\begin{array}{l}\text { Group G-Buf } \\
\text { Tested mineral } \\
\text { mixture }\end{array}$ & \multirow[t]{2}{*}{ P Value } & $\begin{array}{l}\text { Group G- Bov } \\
\text { Mineral mix of } \\
\text { the farm }\end{array}$ & $\begin{array}{l}\text { Group G-Buf } \\
\text { Tested mineral } \\
\text { mixture }\end{array}$ & \multirow{2}{*}{ P Value } \\
\hline & $\begin{array}{l}\text { Mean } \pm \text { standard } \\
\text { deviation }\end{array}$ & $\begin{array}{l}\text { Mean } \pm \text { standard } \\
\text { deviation }\end{array}$ & & $\begin{array}{l}\text { Mean } \pm \text { standard } \\
\text { deviation }\end{array}$ & $\begin{array}{l}\text { Mean } \pm \text { standard } \\
\text { deviation }\end{array}$ & \\
\hline $\mathbf{S C}(\mathrm{cm})$ & $18.94 \pm 1.76$ & $18.93 \pm 1.37$ & 0.9726 & $23.98 \pm 2.07^{b}$ & $25.93 \pm 1.53^{a}$ & 0.0002 \\
\hline LRT (mm) & $35.96 \pm 4.67$ & $36.84 \pm 3.82$ & 0.4531 & $68.36 \pm 7.29^{b}$ & $72.74 \pm 5.53^{a}$ & 0.0149 \\
\hline DRT (mm) & $31.46 \pm 4.60$ & $32.24 \pm 3.73$ & 0.4983 & $41.65 \pm 5.38^{b}$ & $46.54 \pm 3.67^{\mathrm{a}}$ & 0.0002 \\
\hline WRT (mm) & $31.91 \pm 5.27$ & $32.33 \pm 4.01$ & 0.7408 & $41.59 \pm 5.18^{b}$ & $46.33 \pm 3.36^{\mathrm{a}}$ & 0.0002 \\
\hline $\operatorname{VolR}\left(\mathrm{cm}^{3}\right)$ & $61.13 \pm 30.20$ & $62.37 \pm 19.33$ & 0.8577 & $191.69 \pm 60.05^{b}$ & $247.43 \pm 45.50^{\mathrm{a}}$ & 0.0003 \\
\hline LLT (mm) & $35.84 \pm 4.53$ & $36.81 \pm 3.74$ & 0.3960 & $68.92 \pm 7.78^{b}$ & $72.97 \pm 5.68^{a}$ & 0.0334 \\
\hline DLT (mm) & $30.94 \pm 4.29$ & $31.88 \pm 3.79$ & 0.4009 & $41.75 \pm 5.11^{b}$ & $46.39 \pm 3.51^{a}$ & 0.0002 \\
\hline WLT (mm) & $31.71 \pm 5.04$ & $32.34 \pm 3.72$ & 0.6028 & $41.68 \pm 5.01^{b}$ & $46.37 \pm 3.37^{a}$ & 0.0002 \\
\hline VolL $\left(\mathrm{cm}^{3}\right)$ & $59.83 \pm 28.38$ & $62.27 \pm 18.90$ & 0.7113 & $194.56 \pm 62.27^{b}$ & $248.76 \pm 46.94^{a}$ & 0.0007 \\
\hline
\end{tabular}

G-Bov = conventional mineral supplement recommended for bovine cattle; G-Buf = mineral supplement recommended for buffaloes; $\mathrm{SC}=$ scrotal circumference; LRT = right testicle length; DRT = right testicle depth; WRT = right testicle width; VolR = right testicle volume; LLT = left testicle length; DLT = left testicle depth; WLT = left testicle width; VolL = left testicle volume. Different superscript letters on the same line indicate significant differences. 
This increase in testicle size in the G-Buf group may possibly be attributed to mineral supplementation that was better suited to the regional mineral needs, thus clearly demonstrating the positive effect of the mineral supplement tested. This fact supports the idea of Hopper (2014), who stated that lower SC values are related, among other causes, to nutritional effects. In addition, the tested mineral mixture used in the G-Buf group contained higher levels of $\mathrm{Ca}, \mathrm{P}$, and $\mathrm{Cu}$, which are important for the development of the animal, and had a source of yeast, which results in better ruminal digestibility of forage and minerals. Furthermore, the presence of adequate minerals associated with good forage availability increases the plasma levels of estradiol, which plays an important role in the activation of the hypothalamic-pituitary axis, thereby triggering an increase in spermatogenesis and an increase in the size of the testicles (JAVED et al., 1998). In contrast, smaller testicles are associated with decreased gonadotrophic activity (LAND, 1985), which is important for spermatogenesis (PARVINEN, 1982).

In addition to the values obtained for the concentrations of minerals in the seminal plasma of buffaloes (Table 6), some authors described higher concentrations of Fe and Zn (KUMAR et al., 1991; DHAMI et al., 1995) as well as of $\mathrm{Cu}, \mathrm{Co}$, and $\mathrm{Mn}$ (KUMAR et al., 1991; DHAMI et al., 1995, 2001; SHELKE; DHAMI, 2002a,b). The concentrations of Fe in the G-Bov and G-Buf groups, however, were higher than those described by Kanwal et al. (2000), Dhami et al. (2001), and Shelke and Dhami (2002a,b).

Table 6. Means and standard deviations (minimum-maximum) for macroelements ( $\left.\mathrm{mg} \mathrm{dL}^{-1}\right)$ and microelements $(\mu \mathrm{g}$ $\mathrm{dL}^{-1}$ ) in the seminal plasma of young buffaloes reared in intermittent stocking and submitted to different mineral nutritional managements.

\begin{tabular}{ccc}
\hline Variable & G-Bov $(\mathrm{n}=216)$ & G-Buf $(\mathrm{n}=216)$ \\
\hline & Macroelements $\left(\mathrm{mg} \mathrm{dL}^{-1}\right)$ & $14.53 \pm 6.48$ \\
Calcium & $14.09 \pm 6.35$ & $(6.31-38.38)$ \\
& $(5.25-30.33)$ & $3.75 \pm 3.70$ \\
Phosphorus & $3.99 \pm 2.79$ & $(0.43-17.09)$ \\
& $(0.69-13.60)$ & $11.62 \pm 5.18$ \\
Magnesium & $11.65 \pm 8.68$ & $(1.67-31.83)$ \\
\hline & $(0.00-58.99)$ & \\
Copper & Microelements $\left(\mu \mathrm{g} \mathrm{dL}^{-1}\right)$ & $0.17 \pm 0.08$ \\
& $0.18 \pm 0.06$ & $(0.05-0.57)$ \\
Manganese & $(0.08-0.45)$ & $0.09 \pm 0.07$ \\
& $0.05 \pm 0.04$ & $(0.01-0.32)$ \\
Cobalt & $(0.00-0.24)$ & $0.05 \pm 0.05$ \\
& $0.06 \pm 0.05$ & $(0.00-0.22)$ \\
Zinc & $(0.00-0.21)$ & $4.34 \pm 1.58$ \\
& $4.09 \pm 1.02$ & $(1.84-13.78)$ \\
Iron & $(2.98-8.68)$ & $8.40 \pm 2.44$ \\
& $8.03 \pm 2.32$ & $(2.76-17.63)$ \\
\hline
\end{tabular}

G-Bov = conventional mineral supplement recommended for bovine cattle; G-Buf $=$ mineral supplement recommended for buffaloes. Different superscript letters on the same line indicate significant differences $(\mathrm{P}<0.05)$. 
The concentrations of $\mathrm{Ca}$ in the seminal plasma of our animals were close to those cited by Dhami et al. (2001) and Shelke and Dhami (2002a,b), and lower than those described by Sansone et al. (2000) and Eghbali et al. (2010a). The concentrations of $\mathrm{P}$ were lower in relation to those described by Shelke and Dhami (2002a,b). Moreover, the concentrations of $\mathrm{Mg}$ in the seminal plasma of the studied buffaloes were higher than those described by Sansone et al. (2000) and Shelke and Dhami (2002b), and similar to those described by Eghbali et al. (2010a).

The variations of mineral concentrations in seminal plasma observed in our research possibly occurred because of the animals' age, races studied, and nutritional management adopted, among other factors. When comparing the mineral concentrations in the seminal plasma of buffaloes (i.e. mean and standard deviation), differently of our research, a low variability was observed within each of those studies described in the literature. However, an interesting aspect was the number of ejaculates used in each study. In the present study, 432 ejaculates of 54 buffaloes were used, while Dhami et al. (1995) carried out their studies in only five and three animals (40 and 36 ejaculates, respectively). Kumar et al. (1991) also carried out their study in few animals, which differed in age (older animals) and breed. Studies have reported that pubertal bovines had higher concentrations of $\mathrm{Zn}$ in their seminal plasma than do younger animals (UNANIAN et al., 1991). Possibly, the other macroelements and microelements behave in a manner analogous to $\mathrm{Zn}$, being influenced by the animal's age, race, and management.

The only difference between the treatments was observed in the seminal plasma concentrations of $\mathrm{Mn}$, wherein higher values were observed in the G-Buf group $(P<0.05)$. This could probably be attributed to the more adequate availability of this element in the mineral supplement used in this group. This behavior of Mn can be justified by the fact that grass-fed buffaloes may have different mineral needs than do other animals. Because no significant variation was observed in Mn availability in the forage consumed by both the groups, both in the rainy and dry seasons (Table 2), it was inferred that the Mn concentration in the seminal plasma of buffaloes was directly influenced by the type of mineral supplement consumed.

The correlations between mineral concentrations in the seminal plasma of buffaloes and the physical and morphological characteristics of semen are described in Table 7. For the animals in the present study, significant and negative correlations of $\mathrm{Fe}$ concentration with sperm motility and mass motility were antagonistic to the observations of Shelke and Dhami (2002b). P concentrations also showed significant and positive correlations with sperm motility, mass motility, and total head defects. The data obtained in this experiment also contradicted those of Shelke and Dhami (2002b), who did not find correlations between $\mathrm{P}$ concentrations and the characteristics of Jafarabadi buffalo ejaculate. Unanian et al. (1991) and Sansone et al. (2000) stated that $\mathrm{Zn}$ concentrations in seminal plasma did not correlate with the characteristics of the ejaculate, as observed in the present study.

Shelke and Dhami (2002b) reported that $\mathrm{Fe}$ concentrations in seminal plasma showed significant positive correlations with sperm concentration; however, they stated that $\mathrm{Cu}$ concentrations did not have significant correlations with any of the studied variables. In contrast, Co and Mn concentrations showed negative correlations with most of the semen characteristics studied. Moreover, Kareskoski and Katila (2008) observed negative associations of Fe, $\mathrm{Zn}$, and $\mathrm{Cu}$ concentrations in seminal plasma with the volume and sperm concentration of the ejaculate. 


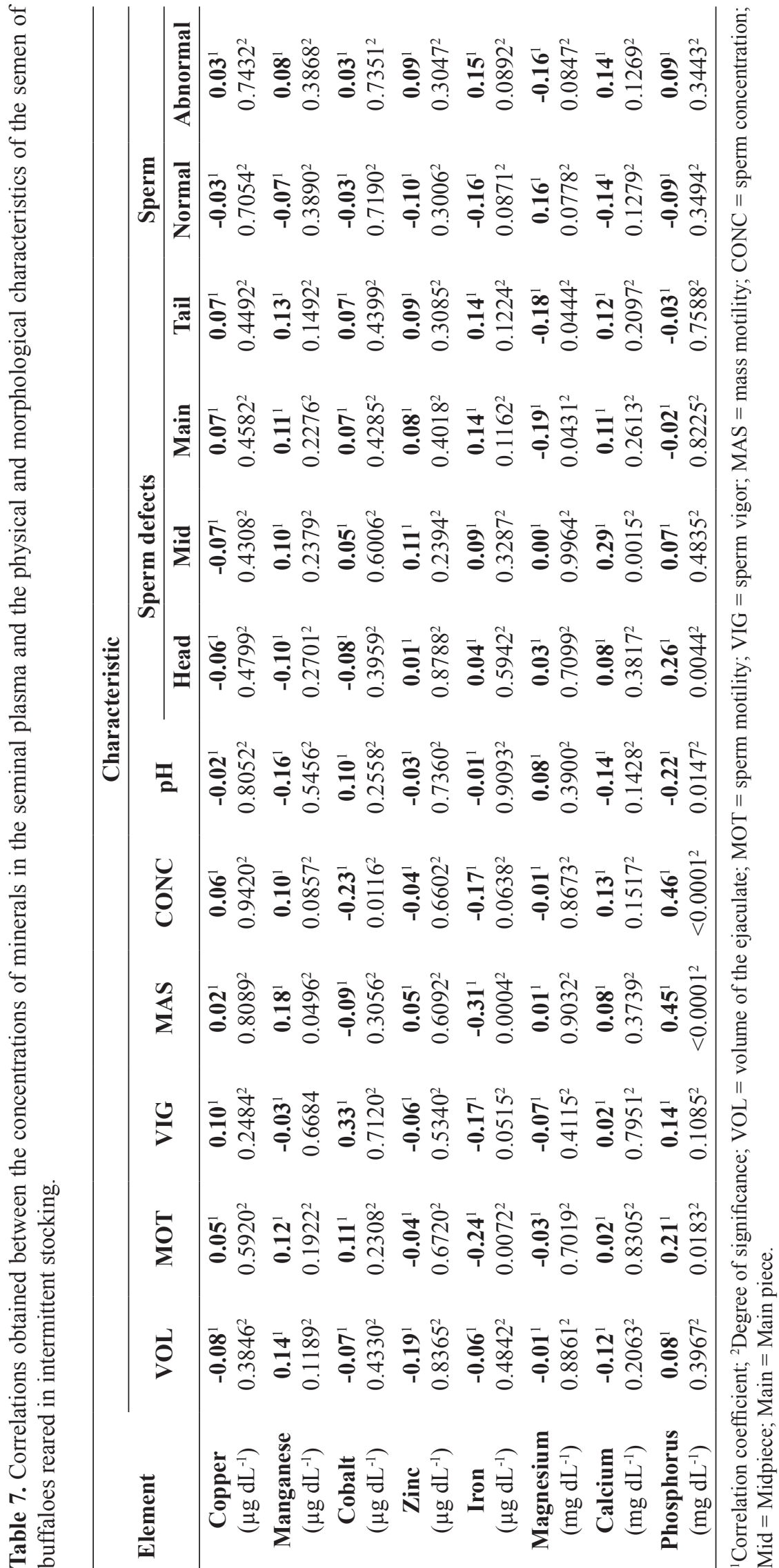


Most correlations observed in our study about $\mathrm{Ca}$ concentration and the physical or morphological characteristics of the ejaculate were not significant, except for the significant negative correlation with seminal pH. Similarly, Shelke and Dhami (2002b) also reported low correlations between $\mathrm{Ca}$ concentrations and the variables studied. The same authors described the non-existence of significant positive correlations between $\mathrm{Mg}$ concentrations and sperm abnormalities and motility; however, the current research showed a low negative correlation between this mineral and the occurrence of head and tail defects in the sperms of buffaloes reared under intermittent stocking. However, Kanwal et al. (2000) reported correlations between $\mathrm{Mg}$ concentrations and ejaculate volume and percentage of dead spermatozoa, while Tvrdá et al. (2013) described significant correlations between $\mathrm{Mn}$ concentrations and sperm motility and progressive motility in cattle.

In relation to the collection method adopted in the present study, according to Barnabe et al. (1992), the concentrations of minerals in seminal plasma were not influenced by the technique of semen collection, since the concentrations of minerals such as $\mathrm{Ca}$ varied similarly irrespective of whether semen was collected through the artificial vagina $\left(6.26 \mathrm{~g} \mathrm{dL}^{-1}\right.$ at $16.52 \mathrm{mg} \mathrm{dL}^{-1}$ ) or by using the electro-ejaculator (10.06 $\mathrm{mg} \mathrm{dL}^{-1}$ to $15.64 \mathrm{mg} \mathrm{dL}^{-1}$ ).

The characteristics of the ejaculate of buffaloes in the G-Buf group could also be associated with the bioavailability of the minerals offered in the supplement. The influence of biologically active inorganic components on the parameters of sperm viability, both in animals and in humans (SØRENSEN et al., 1999; MASSÁNYI et al., 2003), were reported for $\mathrm{Zn}, \mathrm{Mg}$, selenium, and $\mathrm{Ca}$ (MASSÁNYI et al., 2003; EGHBALI et al., 2008; ATIG et al., 2012), with positive effects on sperm motility, morphology, and concentration. The G-Buf group presented greater sperm volume, motility, vigor, and mass motility than did the G-Bov group.
The element $\mathrm{Cu}$ and its compounds, which are essential metal cofactors for a variety of bioactive molecules, were present in greater concentrations in the mineral supplement offered to the G-Buf group. The concentrations of $\mathrm{Cu}$ in the mixture may have favored its bioavailability in the animals, since more adjusted concentrations of $\mathrm{Cu}$ guarantee good sperm morphology (MASSÁNYI et al., 2004; ROYCHOUDHURY et al., 2008). Similarly, other minerals are required for cellular defense systems against free radicals (MARZEC-WRÓBLEWSKA, et al., 2012), and disturbances in their concentrations may lead to the reduction of antioxidant activities and the subsequent risk of developing oxidative stress (MASSÁNYI et al., 2008). The interaction between the mineral element markers of sperm quality and antioxidant profile in semen has been well described in cattle, and any mineral imbalance in seminal plasma or spermatozoa can have a negative impact resulting in sperm abnormalities (TVRDÁ et al., 2013).

The present study describes the concentrations of macroelements and microelements in the seminal plasma of buffaloes supplemented with different mineral formulations in the Amazonia biome of Brazil. This research allows us to conclude that the physical and morphological characteristics of the semen of young buffaloes are influenced by the type of mineral supplementation, with better semen quality in buffaloes supplemented with speciesspecific supplements. Among the minerals present in the seminal plasma of buffaloes, $P$ shows a greater positive correlation with the seminal characteristics in the ejaculate than the other elements.

\section{Acknowledgements}

The authors thank Matsuda LTDA, the Buffalo Breeders Association of Pará, the Government of the State of Pará, and CNPq for the financial support given to this research. 


\section{References}

AHMAD, N.; UMAIR, S.; SHAHAB, M.; ARSLAN, M. Testicular development and establishment of spermatogenesis in Nili-Ravi buffalo bulls. Theriogenology, Philadelphia, v. 73, n. 1, p. 20-25, 2010. DOI: 10.1016/j.theriogenology.2009.06.034.

ANDRABI, S. M. H. Factors affecting the quality of cryopreserved buffalo (Bubalus bubalis) bull spermartozoa. Reproduction in Domestic Animals, Berlin, v. 44, n.3, p. 552-569, 2009. DOI: 10.1111/j.14390531.2008.01240.x

ATIG, F.; RAFFA, M.; BEN-ALI, H.; KERKENI, A.; SAAD, A.; AJINA, M. Impact of seminal trace element and glutathione levels on semen quality of Tunisian infertile men. BMC Urology, London, v. 12, n. 6, p. 2-8, 2012. DOI: $10.1186 / 1471-2490-12-6$

BARNABE, R. C.; BARNABE, V. H.; OLIVEIRA, C. A.; ARRUDA, R. P.; VALENTIM, R.; ZOGNO, M. A. Biochemical study of semen of buffaloes. In: INTERNATIONAL CONGRESS ON ANIMAL REPRODUCTION, 12., 1992, Hague. Proceeding... Netherlands: ICAR, 1992. v. 3, p. 1523-1524.

BARUSELlI, P. S.; SALES, J. N. S.; SALA, R. V.; VIEIRA, L. M.; SÁ FILHO, M. F. History evolution and perspectives of timed artificial insemination programs in Brazil. Animal Reproduction, Belo Horizonte, v. 9, n. 3, p. 139-152, 2012.

CEROVSKY, J. A. A new staining procedure for boar spermatozoa. Živočišná výroba, Praga, v. 21, n. 5, p. 361$366,1976$.

DHAMI, A. J.; MOHAN, G.; SAHNI, K. L. Seminal LDH and trace elements in the static versus motile ejaculates of Friesian and Murrah buffalo bulls. International Journal of Animal Sciences, Dover, v. 10, n. 1, p. 151-156, 1995.

DHAMI, A. J.; SHELKE, V. B.; PATEL, K. P.; PARADVA, J. P.; KAVANI, F. S. Trace minerals profile of blood and seminal plasma of breeding bulls. The Indian Journal of Animal Sciences, New Delhi, v. 71, n. 8, p. 761-763, 2001.

EGHBALI, M.; ALAVI-SHOUSHTARI, S. M.; ASRI REZAII, S. Effects of copper and superoxide dismutase content of seminal plasma on buffalo semen characteristics. Pakistan Journal of Biological Sciences, Dubai, v. 11, n. 15, p. 1964-1968, 2008. DOI: 10.3923/ pjbs.2008.1964.1968

EGHBALI, M.; ALAVI-SHOUSHTARI, S. M.; ASRIREZAEI, S.; ANSARI, M. K. Calcium, Magnesium and Total Antioxidant Capacity (TAC) in Seminal Plasma of Water Buffalo (Bubalus bubalis) Bulls and their
Relationships with Semen Characteristics. Veterinary Research Forum, Urmia, v. 1, n. 1, p. 12-20, 2010 a.

EGHBALI, M.; ALAVI-SHOUSHTARI, S. M.; ASRIREZAEI, S.; ANSARI, M. K. Effects of the seminal plasma iron and lead content on semen quality of water buffalo (Bubalus bubali) bulls. Veterinary Research Forum, Urmia, v. 1, n. 3, p. 142-148, 2010 b.

JAVED, M. T.; KHAN, A.; KAUSAR, R. Influence of age season on body mass, scrotal circumference ande sexaul behaviour os Nili-Ravi buffalo (Bubalus bublais, L.) bulls. Veterinarski Arhiv, Zagreb, v. 68, n. 6, p. 219229, 1998.

KANWAL, M. R.; REHMAN, N. U.; AHMAD, N.; SAMAD, H. A.; ZIA-UR-REHMAN; AKHTAR, N.; ALI, S. Bulk cations and trace elements in the Nili-Ravi buffalo and crossbred cow bull semen. International Journal of Agriculture and Biology, Faisalabad, v. 2, n. 4, p. 302-305, 2000. DOI: $1560-8530 / 2000 / 02-4-302-305$

KARESKOSKI, M.; KATILA, T. Components of stallion seminal plasma and the effects of seminal plasma on sperm longevity. Animal Reproduction Science, Amsterdam, v. 107, n. 3-4, p. 249-256, 2008. DOI: 10.1016/j.anireprosci.2008.04.013

KUMAR, M.; PANGAWKAR, G. R.; KUMAR, R. Effect of filtration on seminal plasma electrolytes in buffalo bull. Indian Veterinary Journal, Chennai, v. 68, n. 1, p. 493-494, 1991.

LAND, R. B. Genetics and reproduction. In: AUSTRALIAN, C. R.; SHORT, R. V. Reproduction in mammals. $2^{\text {th }}$ ed. Cambridge: Cambridge University Press, 1985, p. 93-96.

LUZ, P. A. C.; SANTOS, P. R. S.; ANDRIGHETTO, C.; JORGE, A. M.; ASSIS NETO, A. C. The correlation between age, body weight and testicular parameters in murrah buffalo bulls raised in Brazil. Journal of Reproduction and Development, Tokyo, v. 59, n. 1, p. 147, 2013. DOI: 10.1262/jrd.2012-021

MARZEC-WRÓBLEWSKA， U.; KAMIŃSKI， P.; ŁAKOTA, P. Influence of chemical elements on mammalian spermatozoa. Folia Biologica, v. 58, n. 1, p. 7-12, 2012.

MASSÁNYI, P.; TRANDŽÍK, J.; NAD, P.; KORENEKOVÁ, B.; SKALICKÁ, M.; TOMAN R.; LUKÁC, N.; HALO, M.; STRAPÁK, P. Concentration of copper, iron, zinc, cadmium, lead and nickel in bull and ram semen and relation to the occurrence of pathological spermatozoa. Journal of Environmental Science and Health Part A, Fairfax, v. 39, n. 11-12, p. 3005-3014, 2004. DOI: $10.1081 /$ LESA-200034832 
MASSÁNYI， P.; TRANDŽÍK， J.; NAD， P.; KORENOKOVÁ, B.; SKALICKÁ, M.; TOMAN, R.; LUKÁC, N.; STRAPÁK, P.; HALO, M.; TURCAN, J. Concentration of copper, iron, zinc, cadmium, lead and nickel in boar semen and relation to the spermatozoa quality. Journal of Environmental Science and Health, Part A, Fairfax, v. 38, n. 11, p. 2643-2651, 2003. DOI: 10.1081/ESE-120024453

MASSÁNYI, P.; WEIS, J.; LUKAC, N.; TRANDŽÍK, J.; BYSTRICKA, J. Cadmium, zinc, copper, sodium and potassium concentrations in rooster and turkey semen and their correlation. Journal of Environmental Science and Health, Part A, Fairfax, v. 43, n. 5, p. 563-565, 2008. DOI: $10.1080 / 10934520701796655$

MILLES, S. P. H.; WILKINSON, N. S.; MCDOWELL, L.R. Analysis of minerals for animal nutrition research. $3^{\text {th }}$ ed. Flórida: UFL, 2001. 117 p.

HOPPER, R. M. Breeding Soundness Examination in the Bull. In: Bovine Reproduction, HOPPER, R. M. (Ed.), Mississippi: John Wiley \& Sons, Inc., 2014, cap. 6, p. 58-63. DOI: 10.1002/9781118833971.ch6

PARVINEN, M. Regulation of seminiferous epithelium in bulls. Endocrine Reviews., Washington, v. 3, n. 4, p. 404- 417, 1982. DOI: 10.1210/edrv-3-4-404

PEIXOTO, G. C.; SILVA, M.A.; CASTELO, T. S.; SILVA, A. M.; BEZERRA, J. A.; SOUZA, A. L.; OLIVEIRA, M. F.; SILVA, A. R. Individual variation related to testicular biometry and semen characteristics in collared peccaries (Tayassu Tajacu Linnaeus, 1758). Animal Reproduction Science, Amsterdam, v. 134, n. 3-4, p. 191-196, 2012. DOI: 10.1016/j.anireprosci.2012.08.026

ROYCHOUDHURY, S.; SLIVKOVÁ, J.; BULLA, J.; MASSÁNYI, P. Copper administration alerts fine parameters of spermatozoa motility in vitro. Folia Veterinaria, Czech Republic, v. 52, n. 2, p. 64-68, 2008.

SÁ FILHO, M. F.; BALDRIGHI, J. M.; SALES, J. N. S.; CREPALDI, G. A.; CARVALHO, J. B. P.; BÓ, G. A.; BARUSELLI, P. S. Induction of ovarian follicular wave emergence and ovulation in progestin-based time artificial insemination protocols for Bos indicus cattle. Animal Reproduction Science, Amsterdam, v. 129, n. 3-4, p. 132139, 2011. DOI: 10.1016/j.anireprosci.2011.12.005

SANSONE, G.; NASTRI, M. J. F.; FABBROCINI, A. Storage of buffalo (Bubalus bubalis) semen. Animal Reproduction Science, Amsterdam, v. 62, n. 1-3, p. 5576, 2000. DOI: $10.1016 / \mathrm{S} 0378-4320(00) 00154-8$

SHELKE, V. B.; DHAMI, A. J. Comparative appraisal of blood and seminal plasma biochemistry of Gir and Jafarabadi breeding bulls. Indian Veterinary Journal, Chennai, v. 79, n. 4, p. 349-353, 2002a.
SHELKE, V. B.; DHAMI, A. J. Interrelationships of seminal plasma biochemical, enzymatic and macro-micro mineral profiles with physical attributes and freezability of semen in Jafarabadi bulls. Indian Journal of Animal Sciences, New Delhi, v. 72, n. 5, p. 386-390, 2002b.

SILVA, D. J. Análises de alimentos: métodos químicos e biológicos. 2. ed. Viçosa, MG: UFV, 1998. 165 p.

SØRENSEN, M. B.; BERGDAHL, I. A.; HJØLLUND, N. H. I.; BONDE, J. P. E.; STOLTENBERG, M.; ERNST, E. Zinc, magnesium and calcium in human seminal fluid: relations to other semen parameters and fertility. Molecular Human Reproduction, Oxford, v. 5, n. 4, p. 331-337, 1999.

TVRDÁ, E.; KŇAŽICKÁ, Z; LUKÁČOVÁ, J.; SCHNEIDGENOVÁ, M.; GOC, Z.; GREŃ, A.; SZABÓ, C.; MASSÁNYI, P.; LUKÁČ, N. The impact of lead and cadmium on selected motility, prooxidant and antioxidant parameters of bovine seminal plasma and spermatozoa. Journal of Environmental Science and Health, New Jersey, v. 48, n. 10, p. 1292-1300, 2013. DOI: $10.1080 / 10934529.2013 .777243$

UNANIAN, M. M.; SILVA, A. E. D. F.; DODE, M. A. $\mathrm{N}$. Valores de zinco no plasma seminal de soro sanguíneo de bovinos púberes da raça Nelore relacionados às características espermáticas e desenvolvimento reprodutivo. Pesquisa Agropecuária Brasileira, Brasília, v. 26, n. 4, p. 597-604, 1991.

VALE, W. G. Buffalo production, in the Amazon valley. In: INTERNATIONAL SYMPOSIUM ON BUFFALO PRODUCTS, 1994, Paestum. Proceedings... Paestum: Wageningen press, (EAAP Publication, 82), 1994b. p. 99-108.

VALE, W. G. Collection, processing and deep freezing of buffalo semen. Buffalo Journal, Bangkok, v. 2, suppl. 2, p. $65-81,1994 a$.

VALE, W. G.; OHASHI, O. M.; RIBEIRO, H. F. L.; SOUSA, J. S. Semen freezing and artificial insemination in water buffalo in the Amazon valley. Buffalo Journal, Bangkok, v. 7, n. 2, p. 137-144, 1991.

VIANA, R. B.; BRAGANÇA, G. M.; CARDOSO, E. C.; MONTEIRO, B. M.; ARAÚJO, C. V.; PAZ, G. C.; SOUZA, D. C. Preparo de amostras de plasma seminal de búfalos para determinação de minerais. Revista de Ciências Agrárias, Belém, v. 54, n. 3, p. 208-213, 2011. DOI: $10.4322 /$ rca.2012.016 
